\title{
Reproductive System Findings Original Result Unit
}

National Cancer Institute

\section{Source}

National Cancer Institute. Reproductive System Findings Original Result Unit. NCI

Thesaurus. Code C117645.

The unit of measure for the result of the reproductive system findings test or finding as

originally received or collected. 